\title{
ESTIMATION OF PRODUCTIVITY AND COST OF SMALL-SIZE FULLY-MECHANIZED CUT-TO-LENGTH SYSTEMS
}

\author{
Agris Zimelis, Andis Lazdins, Guntis Saule, Santa Kaleja \\ Latvian State Forest Research Institute "Silava", Latvia \\ agris.zimelis@silava.lv, andis.lazdins@silava.lv, santa.kaleja@silava.lv
}

\begin{abstract}
The study analyses the productivity and costs of compact class forest machines in different types of felling - sanitary felling, thinning, tree plantation, and final felling when sawing undergrowth trees. In accordance with the planned work methods, a productivity forecasting model of harvesting operations has been developed. Productivity and cost are the main challenge in thinning operation, also when a fully-mechanized system is used. The productivity of a harvester significantly affects the costs of mechanized felling, which, in turn, determines if commercial thinning will be profitable. As one of the productivity building areas is the training of operators, the study analyses the effectiveness of training and corresponding productivity changes. The objective of this study is to estimate the productivity and prime cost of roundwood production with Malwa small-sized harvester with a boom length $6 \mathrm{~m}$. The use of small-size machines in different types of felling is possible, if an appropriate work method is used and the diameter of the trees does not exceed the size specified by the manufacturer. The results of the research indicate that it is necessary to choose another technology for sawing seed trees, because the trees are too large for small-size machines. Harvesting productivity depends on dimensions of an average tree. In the diameter class 5.1-9.9 in pre-commercial thinning the productivity was $2.11 \mathrm{~m} 3 \cdot \mathrm{h}-1$, in tending of young stand $1.84 \mathrm{~m} 3 \cdot \mathrm{h}-1$. When working with a small-size harvester, production costs in logging are significantly reduced, if the diameter of extracted trees exceeds $10 \mathrm{~cm}$. The results of the research confirm the appropriateness of the exact technique of thinning. The study results in recommendations of the most efficient methods and development of a productivity predicting model for a small-size wheeled harvester.
\end{abstract}

Keywords: CLT, logging, forest mechanization, Baltic, costs.

\section{Introduction}

Preparation of round timber in the felling site by the cut-to-length (CTL) method is one of the most common timber processing types in the world - including Latvia. For different calculations it is necessary to determine the time consumption for harvesting, typically determining the productivity and analyzing the indicators affecting them. This is mainly necessary for calculating cost calculations or employee salaries. Detailed time studies allow to evaluate the performance of forest machine operators [1], to identify problems associated with work in night shifts [2], to develop productivity forecasting models, to find the most suitable logging machines for specific types of felling and work conditions [3], [4], and to compare seasonal variations of productivity [5].

On-field time-study records mainly demonstrate effectiveness in research, while in real life conditions it would be more appropriate to be based on a dataset offered by the harvester or forwarder IT system. The data records in harvesting machinery provide sufficient amount of information to analyse different productivity indicators by felling types or forest machine operators [6].

Such data analysis is provided mainly for middle-class harvesting machines. The possibilities to use machinery in different types of thinning in Latvia are mainly limited by the mass and width of forest machines. Despite the criteria set, nearly all small and middle-class machines can work in thinning. The total harvested area in 2019 of pre-commercial thinning and thinning is approximately 37000 ha (State Forest Service data on 2019), highlighting significant potential for application of compact class forest machines. Forest thinning is an important forestry work aimed at improvement of the quality of growing stock and increase of incomes from forest management. In Latvia, extensive studies have been conducted so far analysing the effects of different types of disturbances on forest health [7-10].

In 2019 area of salvage logging was about 25000 ha, mostly due to insect damages ( $887 \mathrm{ha}$ ), flooding (517 ha) and wind blows including snow breaks (594 ha) (State Forest Service data on 2019). To deal with consequences of natural disturbances, it is often necessary to remove individual dead trees or their groups leaving the rest of a stand intact. Given the position and spacing of trees, the compactclass forest machines have significant advantages. 


\section{Materials and methods}

In the study logging was performed with a harvester Malwa $560 \mathrm{H}$ and forwarding - with Malwa forwarder $560 \mathrm{~F}$, the specifications of forestry equipment are given in Table 1 . According to the manufacturer's instructions, both machines are recommended for forest thinning.

Table 1

Malwa harvester and forwarder technical parameters

\begin{tabular}{|l|c|c|}
\hline Parameter & $560 \mathrm{H}$ & $560 \mathrm{~F}$ \\
\hline Weight & \multicolumn{2}{|c|}{$5700 \mathrm{~kg}$} \\
\hline Width & \multicolumn{2}{|c|}{$1.95 \mathrm{~m}$} \\
\hline Load area & \multicolumn{2}{|c|}{ Caterpillar C2.8 } \\
\hline Engine & \multicolumn{2}{|c|}{$55 \mathrm{~kW}$} \\
\hline Engine power & \multicolumn{2}{|c|}{$1481 \cdot \mathrm{min}^{-1}$} \\
\hline Hydraulics flow & $6.2 \mathrm{~m}$ & $6.1 \mathrm{~m}$ \\
\hline Crane & $\begin{array}{l}\text { Mowi P40 with harvester } \\
\text { head Log Max 928 A }\end{array}$ & $\begin{array}{c}\text { Cranab FC45 with } \\
\text { indexator rotator }\end{array}$ \\
\hline Facility & \multicolumn{2}{|c|}{6} \\
\hline Number of wheels & \multicolumn{2}{|c|}{$500 \mathrm{~mm}$} \\
\hline Wheels & \multicolumn{2}{|c|}{} \\
\hline
\end{tabular}

Forest machine operators participating in the study have more than 5 years of experience. The study found that the average fuel consumption of the harvester in the experiments was $6 \mathrm{~L}$ per hour and the average consumption of the forwarder was $7 \mathrm{~L}$. The distribution of the number of felled trees in average degrees is expressed by the Weibull equation, the parameters of which were calculated using empirically obtained values. Productivity is expressed as a time consumption per tree or volume unit per employee in a current condition and by the type of felling. The diameter distribution of extracted trees is determined to estimate the average productivity rate. The productivity is expressed as a unit of production per unit of time [13]. The data used in the cost calculations were obtained from a logging service provider that performed detailed cost monitoring. The calculations assume that the price of the harvester base machine is 220000 EUR and the price of the forwarder base machine is 180000 EUR. Depreciation period accepted in the calculations is 5 years, the remaining technical value is $15 \%$. Operators' salaries are calculated at 11 EUR per hour (before taxes). In the cost calculation, the technical readiness is $80 \%$ and the equipment is planned to be loaded one shift per day. Cost analysis is calculated according to the costing model adopted for conditions in Latvia [14].

The selection of study sites is based on typical conditions in forest stands, where the intended harvesting operations are usually implemented. The study sites represent stands, where sanitary (salvage) felling has to be carried out by extracting of individual trees or their groups uprooted or broken by wind, dried or pest-damaged trees (stands with the age between 20 and 40 years). Seed tree harvesting was carried out, comparing two working methods, where the first involves harvesting and forwarding trees by compact class machines and the second working method considering tree felling by chain saw and forwarding using compact class forwarder. Thinning in fast-growing plantation forests has been carried out in poplar and lodge-pole pine stands (20 to 40 years old trees). Harvesting of small undergrowth trees before regenerative felling was carried out in mature coniferous stands by removing of trees with an average DBH of up to $8 \mathrm{~cm}$ and height - at least $1.3 \mathrm{~m}$ before harvesting. In total 27 sites (Table 2) have been harvested in the study with and average size of compartments or group of compartments representing the same type of felling not less than 2 ha.

Harvesting operations at the study sites were carried out by experienced forest machine operators, working in one shift. Duration of the shift is 8 hours, including daily maintenance work (on average for 30 min per shift), and relocation between the study sites. Calculations of productivity of harvesting machinery are based on a time study [11], dividing tracked information into 3 categories. The first category is "Information fields", which includes ID of a working cycle, the DBH of a processed tree and tree species. The second category called "Productive working time" is calculated based on time measurements: 
- reaching trees - the operation starts, when the boom starts moving to a tree, and ends, when the harvester's head touches the tree trunk,

- time for gripping tree: the operation starts, when the harvester head is positioned on a tree stem, and ends, when sawing starts,

- cutting tree: the operation starts, when the positioning of the head is completed, and ends, when the tree is completely sawed off and felled,

- delibming and bucking operation: begins after felling a tree, when feed rollers start moving, and ends, when the last cut is done,

- clearing the undergrowth trees and bushes: sawing of undergrowth trees disturbing extraction of the main stand, while no industrial timber assortment is produced from these trees,

- machine movement: begins,l when the harvester commences the movement, and ends, when the next action is launched,

- other non-conventional operations: these are actions that are needed to carry out the work, but they are not considered in the list of operations or occur rarely; therefore, they are not listed between standard operations, such as repeated gripping of trees, displacement of felled materials, strengthening the strip-roads by loading harvesting residues into strip-road areas with limited ground bearing capacity.

Table 2

Distribution of study sites

\begin{tabular}{|l|c|c|c|}
\hline \multicolumn{1}{|c|}{ Stand type } & $\begin{array}{c}\text { Number of } \\
\text { objects }\end{array}$ & \multicolumn{1}{|c|}{ Technology } & $\begin{array}{c}\text { Average } \\
\text { diameter, cm }\end{array}$ \\
\hline Pre-commercial thinning & 3 & harvester \& forwarder & 10 \\
\hline Tending of young stand & 3 & harvester \& forwarder & 6 \\
\hline Saw undergrowth trees in final felling & 6 & harvester \& forwarder & 7 \\
\hline $\begin{array}{l}\text { Sanitary felling and Sanitary felling } \\
\text { (unsevished trees) }\end{array}$ & 8 & harvester \& forwarder & 13 \\
\hline Seed tree & 2 & chainsaw \& forwarder & 45 \\
\hline Tree plantation - commercial thinning & 3 & harvester \& forwarder & 11 \\
\hline Tree plantation - final felling & 2 & harvester \& forwarder & 13 \\
\hline
\end{tabular}
time.

The third group called "non-productive time" includes no-work activities, e.g., phone calls, resting

Similarly, forwarder productivity calculations are based on the time study. The "Productive working time" category is calculated based on identification of following operations:

- reaching logs: the operation starts when crane movements starts to reach a pile of logs and ends when the grapple touches assortment log,

- gripping logs: the operation starts, when the gripper starts positioning around a log, and ends, when the log is gripped,

- loading logs: the operation starts, when the material is gripped, and ends when the material is appointed to the cargo area of the forwarder,

- arranging logs in bunk: individual action, if operator needs to arrange the material in cargo area,

- driving during loading: driving between piles in the stand,

- driving out/in - leaving (to unload) or entering (to load) the stand,

- putting the slash into the strip-road: if the soil bearing capacity is not sufficient, the operator puts harvesting residues into strip-roads.

Identical operations are counted in the tie study during unloading in a landing area outside the stand. The first and third category of accounted items is similar to the harvester; informative fields include the load size (relative fulfilment) and listing of assortments in the load.

Produced assortments and their standard specifications are listed, prioritizing the most valuable assortments according to the market prices during harvesting [12].

Data processing is performed in Microsoft Excel. Analysis of variance was used to determine whether the type of felling significantly affected the productivity. Descriptive statistics was used to 
describe the mean values. One-factor analysis of variance was used to find out whether there are significant differences between the types of felling in the forwarding process.

\section{Results and discussion}

Working time records, depending on the type of felling and distribution of diameter classes, productive time expressed per production unit (excluding unrelated activities), and the number of trees to be processed during a productive hour (Table 3 ).

Table 3

\section{Characteristics in tending}

\begin{tabular}{|c|c|c|c|c|c|c|}
\hline Stand type & $\begin{array}{l}\text { Diameter } \\
\text { class, } \mathrm{cm}\end{array}$ & $\begin{array}{l}\text { Percentage } \\
\text { of total } \\
\text { number of } \\
\text { trees, } \%\end{array}$ & $\begin{array}{l}\text { Average tree, } \\
\mathbf{m}^{3}\end{array}$ & $\begin{array}{c}\text { Productivity, } \\
\text { m }^{3} \text { in a } \\
\text { productive } \\
\text { hour, } \mathbf{m}^{3} \cdot \mathbf{h}^{-1}\end{array}$ & $\begin{array}{c}\text { Number of } \\
\text { trees } \\
\text { processed per } \\
\text { productive } \\
\text { working hour }\end{array}$ & $\begin{array}{c}\text { Harvester } \\
\text { costs, } \\
\text { EUR } \cdot \mathbf{m}^{-3}\end{array}$ \\
\hline \multirow{4}{*}{$\begin{array}{l}\text { Pre- } \\
\text { commercial } \\
\text { thinning }\end{array}$} & $\geq 5$ & 20 & $0.01 \pm 0.0001$ & 0.55 & 120 & 83.8 \\
\hline & $5.1-9.9$ & 43 & $0.02 \pm 0.0003$ & 2.11 & 91 & 21.8 \\
\hline & $10-11.9$ & 21 & $0.06 \pm 0.0005$ & 4.49 & 77 & 10.3 \\
\hline & $\leq 13$ & 16 & $0.12 \pm 0.0018$ & 6.99 & 57 & 6.6 \\
\hline \multirow[t]{3}{*}{ Thinning } & $\geq 5$ & 50 & $0.01 \pm 0.0003$ & 0.58 & 113 & 79.4 \\
\hline & $5.1-9.9$ & 48 & $0.02 \pm 0.0008$ & 1.84 & 97 & 25.0 \\
\hline & $10-11.9$ & 2 & $0.05 \pm 0.0046$ & 4.86 & 90 & 9.5 \\
\hline \multirow{4}{*}{$\begin{array}{l}\text { Saw } \\
\text { undergrowth } \\
\text { trees in final } \\
\text { felling }\end{array}$} & $\geq 5$ & 46 & $0.01 \pm 0.0001$ & 0.50 & 176 & 92.1 \\
\hline & $5.1-9.9$ & 31 & $0.02 \pm 0.0006$ & 2.62 & 119 & 17.6 \\
\hline & 10-11.9 & 19 & $0.06 \pm 0.0009$ & 6.13 & 105 & 7.5 \\
\hline & $\leq 13$ & 4 & $0.1 \pm 0.0033$ & 6.96 & 68 & 6.6 \\
\hline \multirow{4}{*}{$\begin{array}{l}\text { Sanitary } \\
\text { felling (dead } \\
\text { trees) }\end{array}$} & $\geq 5$ & 3 & $0.01 \pm 0.0006$ & 0.53 & 101 & 86.9 \\
\hline & $5.1-9.9$ & 23 & $0.03 \pm 0.0009$ & 2.07 & 81 & 22.3 \\
\hline & $10-11.9$ & 24 & $0.06 \pm 0.0011$ & 3.14 & 52 & 14.7 \\
\hline & $\leq 13$ & 50 & $0.18 \pm 0.0141$ & 8.61 & 56 & 5.4 \\
\hline \multirow{4}{*}{$\begin{array}{l}\text { Sanitary } \\
\text { felling }\end{array}$} & $\geq 5$ & 10 & $0.01 \pm 0.0001$ & 0.67 & 133 & 68.8 \\
\hline & $5.1-9.9$ & 34 & $0.02 \pm 0.0003$ & 2.44 & 101 & 18.9 \\
\hline & $10-11.9$ & 29 & $0.06 \pm 0.0005$ & 5.01 & 85 & 9.2 \\
\hline & $\leq 13$ & 26 & $0.14 \pm 0.0026$ & 8.39 & 63 & 5.5 \\
\hline \multirow{4}{*}{$\begin{array}{l}\text { Tree } \\
\text { plantation - } \\
\text { commercial } \\
\text { thinning }\end{array}$} & $\geq 5$ & 3 & $0.01 \pm 0.0003$ & 0.70 & 112 & 65.8 \\
\hline & $5.1-9.9$ & 36 & $0.03 \pm 0.0005$ & 3.07 & 115 & 15.0 \\
\hline & $10-11.9$ & 28 & $0.06 \pm 0.0006$ & 6.21 & 99 & 7.4 \\
\hline & $\leq 13$ & 33 & $0.17 \pm 0.0041$ & 10.96 & 66 & 4.2 \\
\hline \multirow{4}{*}{$\begin{array}{l}\text { Tree } \\
\text { plantation - } \\
\text { final felling }\end{array}$} & $\geq 5$ & 3 & $0.01 \pm 0.0004$ & 0.62 & 102 & 74.3 \\
\hline & $5.1-9.9$ & 13 & $0.03 \pm 0.0008$ & 3.10 & 112 & 14.9 \\
\hline & $10-11.9$ & 22 & $0.07 \pm 0.0007$ & 6.02 & 91 & 7.7 \\
\hline & $\leq 13$ & 62 & $0.14 \pm 0.0014$ & 9.57 & 70 & 4.8 \\
\hline
\end{tabular}

The obtained data show that the type of felling has a significant $(p<0.05)$ impact on the average productivity indicators and is significantly influenced by the dimensions of the average processed tree. Productivity indicators do not significantly differ from the middle-class machines in operations, such as thinning, where the productivity of middle-class harvesters is ranging from 4 to $11 \mathrm{~m}^{3} \cdot \mathrm{h}^{-1}$ (Latvian State Forest data on harvester productivity in thinning 2019). 
Selection of an appropriate working method for different harvesting operations is crucial for efficient production of roundwood. Extraction of seed trees starts with the planning process, which includes marking of strip-roads, identification of landing site, and assessing whether there are no dangerous trees before starting the work. Felling of trees should be done by a chainsaw, and a compactclass Malwa forwarder can be used for off-road transport. According to the results of the study, felling of seed trees with a compact-class harvester is not recommended. The maximum opening of the felling head is too small for gripping, delimbing and bucking, and therefore this work has to be done manually. Before forwarding, regulation is required, mainly to adopt the manipulator pressure (hand-lever calibration, minimum and maximum power adjustment) [15], the correct entry of parameters indicates the "fluent" operation of the machine, this means that the machine is working without twitching and sharp movements that reduce fuel consumption and ensure machinery longevity (technical regulation is not dependent on the felling type). Following the data obtained in the study, the most appropriate working method for forwarding of seed trees involves: loading starting with the tree butt-end part (cutting 1), the forwarder drives up to timber logs and starts their pulling in the cargo area from the buttend. The pulling can be combined with movement, which means that by lifting the part of the beam it is possible to pass under the material, thus facilitating the pulling process (more optimal appointment of the material of the bogie should be done sideways, but not always possible). Then, if movement with a forwarder is not recommended, it is necessary to intercept the log, at $1 / 3$ of the length from the bottom end, and to pull the log into the loading space keeping the boom in parallel to the log laying direction. During loading of the second and third log the same approach can be used, but when the cut-off measures the possibility of lifting it completely, then the appointment of the log should be performed as far as possible with less time consumption. The process of forwarding of seed trees with a compact-class forwarder must be implemented tree by tree, forwarding at once logs produced from a single stem.

Harvesting of small dimension trees in thinning and final felling should be organized in respect to the following forest management process. In case of mechanized extraction of undergrowth trees and bushes before regenerative felling with medium-class machines, the recommended working method for compact-class machines requires strip-roads should be planned in such a way that they are located between planned strip-roads for medium-class machines, $5 \mathrm{~m}$ form mid-axis of the planned strip road. The felled material (small dimension trees) should be piled in compact stacks by cutting them into approximately $3 \mathrm{~m}$ long logs. Stacking the biomass at the external boundaries of the planned strip-roads, thereby improving accessibility of biomass during forwarding. In thinning of plantations of fast-growing trees with regular rows of planted trees harvesting with a compact-class machines should be planned in $45^{\circ}$ angle against the rows of trees. Logging residues should be piled into strip-roads to avoid root damages. Trees should be felled at approximately $45^{\circ}$ angle against a longitudinal axis of the strip-road or perpendicular to the strip-road. Extraction should be started with trees located on the planned striproad, but no further than half of the boom length. Trees that are located in a longer distance from the harvester should be sawn when the harvester changes position. The mean moving distance between parking lots is $1 \mathrm{~m}$. Trees located on the strip-roads are harvested perpendicularly to the strip-road, ensuring that logs are stacked in compact piles along the strip-road. Harvesting is planned in sectors, starting harvesting from the right or left edge sawing trees that interfere with the growth of other trees. Harvesting is planned in sectors, trees are extracted starting from the right or left edge, initially cutting trees that interfere with the growth of the target trees. The length of a sector across the strip-roads depends on the boom length, but in perpendicular to the strip-roads a sector has to be divided into 2 zones - zone 1 is up to $60 \%$ of the boom length. Here trees are felled towards the strip-road. In zone 2 (about 60-100\% of the boom outreach), trees should be felled away from the strip-road and pulled over or the strip-road, so that logs are piled along the strip-road and harvesting residues are stacked in piles behind piles of logs or on the strip-road. The log position depends on the harvesting method, bigger logs are located closer to the strip-roads and smaller logs are piled in a longer distance from the strip-roads, thereby providing optimal working conditions for the forwarder.

In the forwarding process, the average loaded load was $4.0 \mathrm{~m}^{3}$. Bigger loads are transported from salvage felling and forest plantations. This difference is due to the number and location of logs. The highest forwarding productivity has been achieved in sanitary felling (Table 4) due to significantly bigger volume of the forwarded logs. There is statistical difference in productivity between the stand 
types ( $\mathrm{p}<0.05)$, this can be explained by the location of the material in the felling area, as a result the forwarder needs to move more along the felling area to fill up load.

Given the specificity of sanitary cuttings, the achieved indicators are rated as very high, especially given that the establishment of technological corridors was not necessary. This means that, where appropriate, a forwarder can move between growing trees, thus reducing the total driving distance and avoiding damages of living trees in the stand.

Main productivity indicators

\begin{tabular}{|l|c|c|c|c|}
\hline \multicolumn{1}{|c|}{ Stand type } & \multicolumn{1}{|c|}{$\begin{array}{c}\text { Average } \\
\text { load, } \mathbf{m}^{\mathbf{3}}\end{array}$} & $\begin{array}{c}\text { Productivity, } \mathbf{~ m}^{\mathbf{3}} \\
\text { per productive } \\
\text { hour }\end{array}$ & $\begin{array}{c}\text { Productive work } \\
\text { time per load, } \\
\text { min. }\end{array}$ & $\begin{array}{c}\text { Forwarding } \\
\text { cost, EUR· } \mathbf{m}^{-3}\end{array}$ \\
\hline $\begin{array}{l}\text { Pre-commercial } \\
\text { thinning }\end{array}$ & $4.45 \pm 0.14$ & 6.2 & 39.8 & 4.21 \\
\hline $\begin{array}{l}\text { Extraction of } \\
\text { undergrowth trees } \\
\text { before regenerative } \\
\text { felling }\end{array}$ & $4.14 \pm 0.08$ & 7.1 & 33.9 & 6.02 \\
\hline $\begin{array}{l}\text { Sanitary felling } \\
\text { (extraction of dead } \\
\text { trees) }\end{array}$ & $4.03 \pm 0.29$ & 10.5 & 26.4 & 5.28 \\
\hline $\begin{array}{l}\text { Forest plantations }- \\
\text { regenerative felling }\end{array}$ & $4.59 \pm 0.14$ & 5.3 & 41.5 & 6.27 \\
\hline $\begin{array}{l}\text { Forest plantations }- \\
\text { commercial thinning }\end{array}$ & $4.03 \pm 0.19$ & 5.8 & 44.0 & 7.05 \\
\hline
\end{tabular}

\section{Conclusions}

1. The size of extracted trees is an essential factor determining productivity during production of roundwood $\log \mathrm{s}$ in all of the studied felling types. This factor affects not only the productivity and cost, but also sets limits for stands suitable for mechanized harvesting, if the size of the trees is bigger than the harvester head opening. In such cases it is necessary to cut and to process trees with chainsaws.

2. The production costs are significantly smaller in harvesting operations, if the diameter of extracted trees exceeds $10 \mathrm{~cm}$; however, considerable proportion of undergrowth trees reduces average productivity.

3. The research data indicate effective use of small-size harvesters in different types of felling. The productivity achieved in the studied types of fellings is relatively high in comparison to the values achieved by middle size harvesters.

4. Extraction of large trees in pre-commercial thinning with a compact-class harvester is not technically feasible, but if supplemented by teams of workers with chainsaws, then even larger logs can be forwarded with a compact-class forwarder; however, dimensions of logs should be considered.

\section{Acknowledgements}

The study was implemented within the scope of the Forest Sector Competence Centre of Latvia No 1.2.1.1/18/A/004 "Alternative harvesting solutions for non-conventional felling types".

\section{References}

[1] Purfuerst F. T. Learning curves of harvester operators. Croatian Journal of Forest Engineering, 31(2), 2010. Pp. 89-97.

[2] Bembenek M., Tsioras P.A., Karaszewski Z., Zawieja B., Bakinowska E., Mederski P.S. Effect of day or night and cumulative shift time on the frequency of tree damage during CTL harvesting in various stand conditions. Forests, vol. 11, 2020, p. 743. DOI: 10.3390/f11070743. 
[3] Stampfer K., Steinmüller T. A new approach to drive a productivity model for the harvester 'Valmet 911 Snake'. Proceedings The International Mountain Logging and 11th Pacific Northwest Skyline Symposium, 2001. pp. 254-262.

[4] Liski E., Jounela P., Korpunen H., Sosa A., Lindroos O., Jylhä P. Modeling the productivity of mechanized CTL harvesting with statistical machine learning methods. International Journal of Forest Engineering, vol. 31 (3), 2020, pp. 253-262, DOI: 10.1080/14942119.2020.1820750.

[5] Grzywí Nski W., Turowski R., Naskrent B., Jelonek T., Tomczak A. The impact of season on productivity and time consumption in timber harvesting from young Alder stands in lowland Poland. Forest, vol. 11 (10), 2020, DOI: 10.3390/f11101081.

[6] Arlinger J., Möller J. Introduction to StanForD 2010. Uppsala, 2010. [online] [21.03.2021] Available at:

https://www.skogforsk.se/contentassets/1a68cdce4af1462ead048b7a5ef1cc06/stanford-2010introduction-150826.pdf.

[7] Snepsts G., Kitenberga M., Elferts D., Donis J., Jansons A. Stem damage modifies the impact of wind on Norway spruces. Faorest, vol. 11(4):463, 2020, DOI: 10.3390/f11040463.

[8] Donis J., Rokpelnis M., Snepsts G., Zarins J. Extreme wind speeds as a natural disturbance agent in spruce forests in Latvia. Proceeding of the 2th International Conference Wind Effects on Tree, 2009, pp. 163-167.

[9] Pourghodrat A., Nelson C.A., Phillips K.J., Fateh M. Improving an energy harvesting device for railroad safety applications. Proceeding. Active and Passive Smart Structures and Integrated Systems 2011, Mar. 2011, vol. 7977, p. 79770U, DOI: 10.1117/12.880631.

[10] Donis J., Kitenberga M., Šnepsts G., Dubrovskis E., Jansons Ā. Factors affecting windstorm damage at the stand level in hemiboreal forest in Latvia: case study of 2005. Silva Fennica, vol. 52(4), 2018, DOI: 10.14214/sf.10009.

[11] Lazdiņš A., Prindulis U., Kalēja S., Daugaviete M., Zimelis A. Productivity of Vimek 404 T5 harvester and Vimek 610 forwarder in early thinning. Agronomy Research, vol. 14(2), 2016, pp. 475-484.

[12] Juhṇēvičs G. Apaḷo kokmateriāku kvalitātes prasības (Quality requrements for round timber). Rīga, 2017. 57 p. (in Latvian). [online]. Available: https://www.vmf.lv/site/upload/MI 02.09 Apalo kokmaterialu kvalitates prasibas 12 v.pdf.

[13] Sarmulis Z., Saveljevs A. Meža darbi un tehnologijas (Forest works and technologies). Jelgava: Studentu biedrība "Šalkone," 2015 (In Latvian).

[14] Kalēja S., Lazdiņš A., Zimelis A., Spalva G. Model for cost calculation and sensitivity analysis of forest operations. Agronomy Research, vol. 16(5), 2018, pp. 2068-2078, DOI: $10.15159 / A R .18 .207$.

[15] Heinze A.A. Modelling, simulation and control of a hydraulic crane. 2007. [online] [21.03.2021] Available at : https://www.diva-portal.org/smash/get/diva2:205807/FULLTEXT01.pdf. 